\title{
MAKING THE MOON COME TRUE
}

I have said it before: the streetlight on the corner is not the moon;

it is controlled by an energy

cell at the nape of the neck,

and it responds only to

the absence of light. Furthermore

during the day I have seen him come, the man in the yellow truck

to replace the glass sclera and

I know what you're going to say but

I refuse to speak of it; the streetlight on the corner is not an eye.

\section{A GARLAND OF TEETH}

We are all smiling: perhaps because

of the sun we tilt our heads

forward and pull our hats

down over the eyes. But the casual

stance remains: one in the front

even crosses his left leg over the right,

tucks his thumb into his vest

and leans on his cane. Fine. 
In the back row someone is holding

a garbage can cover behind a woman's

head. We are making progress. See?

Most of us are showing you

the insides of our hands.

Robert L. McRoberts

\section{DESERTIONS}

I have deserted the causes

of my dreams.

The men I adore have perished.

The women

open their blouses and air

falls out, plump and empty.

I have deserted the music of my friends;

dark notes, fantasies.

I have taken my destiny out of their soft hands.

All my country, its vast lakes of despair, its mountains, equal to a single pebble in my shoe, a dampness beneath the sun's perception.

A man passes me on the street. His face is like my father's; strong and old:

A sycamore by a white stream-

And I desert him; even as I pass I am deserting him, leaf by leaf, each light branch, vanishing. 